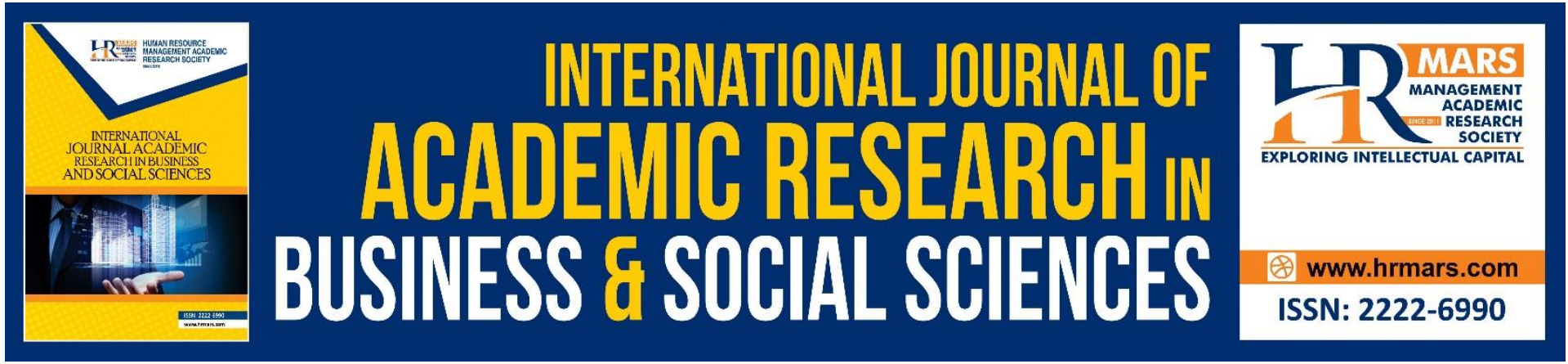

\title{
An Overview of Corporate Social Innovation (CSI)
}

Nur Diyana Mustapha, Muhamad Nizam Jali, Nurisyal Muhamad

To Link this Article: http://dx.doi.org/10.6007/IJARBSS/v11-i7/10527

DOI:10.6007/IJARBSS/v11-i7/10527

Received: 19 May 2021, Revised: 21 June 2021, Accepted: 15 June 2021

Published Online: 30 July 2021

In-Text Citation: (Mustapha et al., 2021)

To Cite this Article: Mustapha, N. D., Jali, M. N., \& Muhamad, N. (2021). An Overview of Corporate Social Innovation (CSI). International Journal of Academic Research in Business and Social Sciences, 11(7), 691698.

Copyright: @ 2021 The Author(s)

Published by Human Resource Management Academic Research Society (www.hrmars.com)

This article is published under the Creative Commons Attribution (CC BY 4.0) license. Anyone may reproduce, distribute, translate and create derivative works of this article (for both commercial and non-commercial purposes), subject to full attribution to the original publication and authors. The full terms of this license may be seen

at: http://creativecommons.org/licences/by/4.0/legalcode

Vol. 11, No. 7, 2021, Pg. 691 - 698

http://hrmars.com/index.php/pages/detail/IJARBSS

JOURNAL HOMEPAGE

Full Terms \& Conditions of access and use can be found at http://hrmars.com/index.php/pages/detail/publication-ethics 


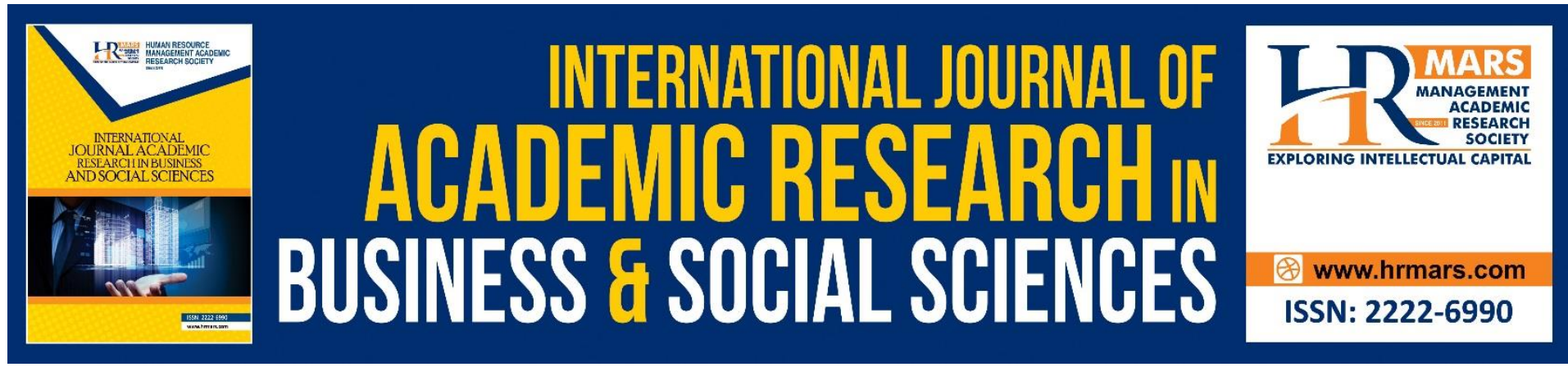

\title{
An Overview of Corporate Social Innovation (CSI)
}

\author{
Nur Diyana Mustapha, Muhamad Nizam Jali, Nurisyal \\ Muhamad \\ UCSI University, Malaysia, Kolej Universiti Polytech Mara, Malaysia
}

\begin{abstract}
This paper highlights the variety of social innovation and corporate social innovation definitions, and concepts that have been proposed by scholars in the area of sociology, technological innovations and economics. However, there is no commonly agreed definition, as it depends on the multidisciplinary field, sector and country. In particular, the concept from the business perspective is still vague. This study discovered that widespread ambiguities and vagueness dominate the concept of social innovation in general, making it difficult to reach a common, unifying definition. Thus, this aims to analyze the contributions, discussions and arguments of corporate social innovation (CSI) to be used as guidance for practitioners in business corporations to understand how the concept can be implemented. Keywords: Technological Innovation, Social Innovation, Corporate Social Innovation, Social Issues, Economic Issues, Environmental Issue
\end{abstract}

\section{Introduction}

The concept of social innovation has been broadly discussed especially in the area of technology innovations and society development. However, the concept of corporate social innovation in corporate been questioned with multiple meanings and the empirical studies are still at its infancy stage. Therefore, firstly this paper explores the definition of social innovation in general and secondly, highlights the corporate social innovation concepts that have been discussed by scholars particularly in the area of business strategy implementation. In this article, the focus is on organizations as main drivers of innovation.

\section{Literature Review \\ Social Innovation}

The concept of innovation has its historical origins in the early 1880s, when Schumpeter (1939) characterized the capitalist system and emphasized technological innovations as proficient, commercial, and beneficial to shareholders (Phillips et al., 2015). This idea is supported by previous literature which more focused on performance, profitability, and picture of the organization's benefit (Esen, \& Maden-Eyiusta, 2019; Tabares, 2020). According to the OECD (2005), presented in the Oslo Manual, innovation is divided into four types: product, process, organizational, and marketing innovation, all of which affect an individual, group, organization, or society as a whole. 
Social innovation was gradually introduced in the research hub in the year 1986 and only began to evolve in the year 2003 with flooded thematic in the research field. Initially, social innovation has been introduced particularly to public policies which are sensitive to the public services and closely to the public interest in responding to social challenges (Nicholls et al., 2016) such as: behavioural issues, health and social issues, environmental inequality, poor standard of living and education system, income inequality, and high unemployment rate (Nicholls et al., 2016; Mariann \& Krisztina, 2018)

As the current environment is concerned about social worth, another worldview of society from the concept of social innovation is made to produce better approaches (Dionisio and de Vargas, 2020). As a result, social innovation has emerged as a solution that addresses a variety of social concerns and encourages the adoption of an innovative culture. According to previous literature, social innovation first appeared around the year 2010, and is primarily defined as a social outcome that primarily solves social challenges (Mulgan et al. 2007; Howaldt \& Hochgerner, 2016; Mariann \& Krisztina, 2018;) specifically to provide solutions for social challenges (Cajaiba-Santana, 2014) and meet social goals (Phills et al., 2008; Altuna et al., 2015, Mirvis et al. 2016 ; Mariann \& Krisztina, 2018). Some author focus on the actor that engaged in social innovation system which divided into micro, meso, macro, and global level that defining features of social innovation based on its own internal logic ( Nicholls et al., 2016; Kocziszky et al., 2017).

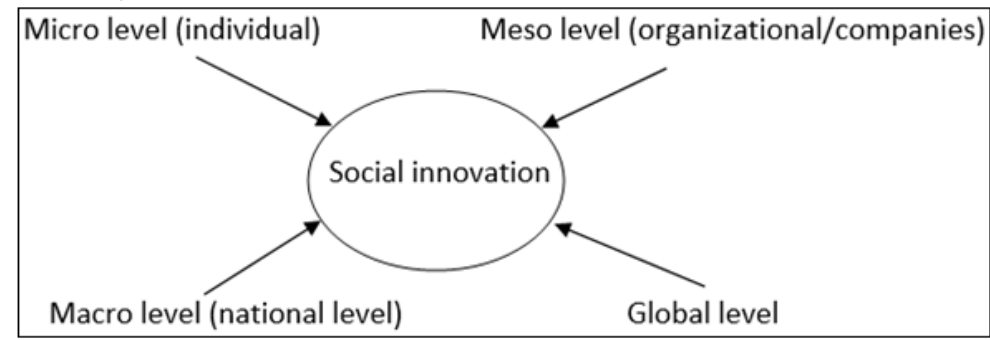

Figure 1: Levels of social innovation (adapted from Kocziszky et al., 2017)

In 21st century, social innovation (SI) rose to encourage societal nature and also economics nature. There is an active debate with Drucker (1985) about whether social innovation can add value to economic organizations. Unfortunately, the concept of social innovation lacks a strong conceptual foundation and does not focus on a specific field (Nicholls et al., 2016). Few authors argue that social innovations may not be suitable for all types of actors, but only relevance to a few sectors such as government, public services, social enterprise, not-for-profit organizations, NGOs, and so on (CRISES, 2010, Voorberg, Bekkers, \& Tummers, 2015; Cajaiba-Santana, 2014; Tabares, 2020).

Table 1 expedited the concept of social innovation that relates to the development of social innovation from first period to latest era. 
Table 1. Definition of social innovation

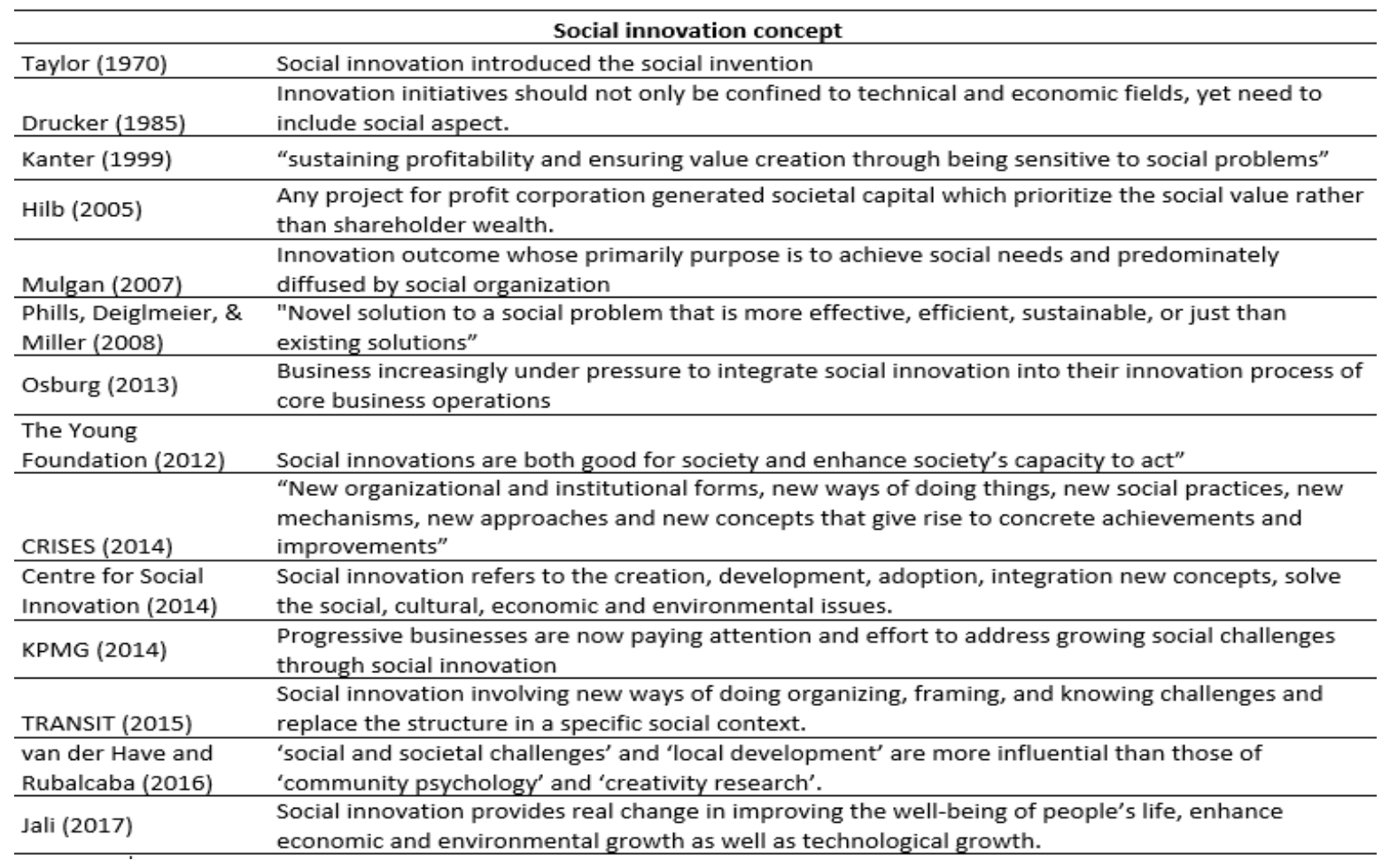

\section{Corporate Social Innovation}

Kanter (1999) departed the concept of corporate social innovation from social innovation since the impact of business on society is the major concern in the discussion (Tabares, 2020; Dionisio and de Vargas, 2020). As there are no formal definitions of corporate social innovation, the concept of social innovation at the corporate level are applied (Carrillo \& Gomi, 2017; Dionisio and de Vargas, 2020).

However, the literature does not give a solid foundation and is immature (Phillis et al., 2008; Nicholls et al., 2016). According to some literature, there is a lack of clarity on corporate social innovation theory as a result of a gray area between corporate social innovation and social innovation, as well as a lack of clarity on corporate social innovation theory (Baker \& Mehmood, 2015; Van der Have and Rubalcaba, 2016). Certainly, research on corporate social innovation has remained absent in the literature as the enthusiasm more towards social innovation instead of corporate social innovation (Martinez et al., 2017; Tabares, 2020). According to the previous literature, the current literature does not appear to reach a unified understanding and is unlikely to reach any consensus in the academic field due to the multidisciplinary nature of the field (Gagliardi, \& Cox, 2018). Even though some companies have embraced corporate social innovation, there is still a lot of skepticism, especially the involvement of social initiatives by employees, external stakeholders and business benefit (Van der Have \& Rubalcaba, 2016; Dionisio and de Vargas, 2020). 
Table 2. Definition of corporate social innovation

\begin{tabular}{ll}
\hline & \multicolumn{1}{c}{ Corporate social innovation concept } \\
\hline Mirvis et al., (2016) & $\begin{array}{l}\text { Corporate Social Innovation (CSI) aims shareholder and social value with the potential to alter the } \\
\text { structure of innovation systems, improve employee motivation, and change corporate identities } \\
\text { and strategies to increase competitive advantage, while at the same time bringing solutions to } \\
\text { societal needs }\end{array}$ \\
\hline Howaldt (2016) & $\begin{array}{l}\text { CSI is an opportunity and innovation strategies for corporate businesses to deal with the } \\
\text { development of new business areas. }\end{array}$ \\
\hline SIC Research Landscape Expert & There is still a disconnect between social innovation and the corporate social responsibility. \\
\hline Dionisio \& de Vargas (2020) & $\begin{array}{l}\text { Corporate social innovation socially oriented goals were demanded by stakeholders in general, } \\
\text { representing a generational shift in how business was perceived and how it related with society } \\
\text { and the natural environment, and how ever more this shift demanded a need for institutional } \\
\text { changes and adopting new strategies and business models }\end{array}$ \\
\hline
\end{tabular}

Table 2 expedited corporate social innovation as a business model, in improving human well-being with fulfillment of sustainable development goals objectives (SDGs), which focusing on a superior world is 2030 (European Commission 2013; Esen and Maden-Eyiusta, 2019). From perspective Mirvis et al (2016), corporate social innovation combines a unique set of corporate assets including managerial capacities, marketing skills, technology, human resource in creating solutions to economic, social, and environmental for sustainability and society worth. Some author claims that corporate social innovation are appears as socially responsiveness towards business and social challenges which suitable to be recognized as culture in the organization' success (Esen, \& Maden-Eyiusta, 2019).

Furthermore, Table 2 depicts the arguments of corporate social innovation, which appear as the role of an investment in a social and environmentally relevant context that is also relevant to business investment (Mirvis et al., 2016). In addition, the previous literature states that companies do not exist solely to maximize the shareholder value in shaping the purpose of businesses, but rather allows them to share their profit to serve society by producing products and services at affordable prices, or giving people ownership in a business (Odunlade, 2017). Therefore, corporate social innovation is important by introducing the social dimension during the process of innovation when the novelty of the product, process or services, eventually social needs are fulfilled.

\section{A Framework of Corporate Social Innovation}

Based on the discussion above, this study proposed a corporate social innovation framework with three pillars: social, economic, and environmental elements. Corporate social innovation usually has a social objective anchored within social goals (Mulgan et al., 2007; Kocziszky et al., 2017). A couple of researchers believe corporate social innovation is a business model that explicitly addresses a social challenge which has become the socially relevant innovation system and discovered as corporate culture that can be source of competitive advantage in organizations (Kocziszky et al., 2017; Dionisio and de Vargas, 2020). As a result, when organizations invest in corporate social innovation exercises, network interactions among stakeholders such as management, employees, suppliers, and customers will improve.

The second element is economics. As indicated by Cajaiba-Santana (2014), it isn't right when social innovation is simply only associated with the social advantage results. As a result, social innovations can be mentioned as a component of the Sustainable Development Goals (SDG), because economic in terms of manageable yields of social, financial, and mechanical innovation (Mariann \& Krisztina, 2018; Dionisio and de Vargas, 2020) were incorporated into products, cycles, and services in tending to complex technology adoption, socio-economic 
improvement. Corporate social innovations create new unexplored markets and meet stakeholders' expectations more proactively towards a more sustainable pattern of business growth and sustainable development relative to social needs (Mirvis et al., 2016). Thus, the economics very important to move forward to achieve SDG's mission of 2030. (Mulgan et al., 2007; Altuna et al, 2015).

Finally, element in the corporate social innovation is environmental aspect where the businesses integrating the environmental responsibility into their policies and operations in creating the business wealth, which applying the transparent environment engagement and accountability when creating in the innovation of products and processes (see (Schwab, 2015). According to KPMG (2014), business will be experiencing to heavily environmental and social changes over the next 20 years that meets the highest standards of verified environmental performance and has a long-standing reputation for being socially responsible. Therefore, through CSI, companies focus on how society and the natural environment related as the platforms of investment in integrating social value and environmental value strategies in the corporate business plans (Birchall, et al., 2014; Dionisio and de Vargas, 2020).
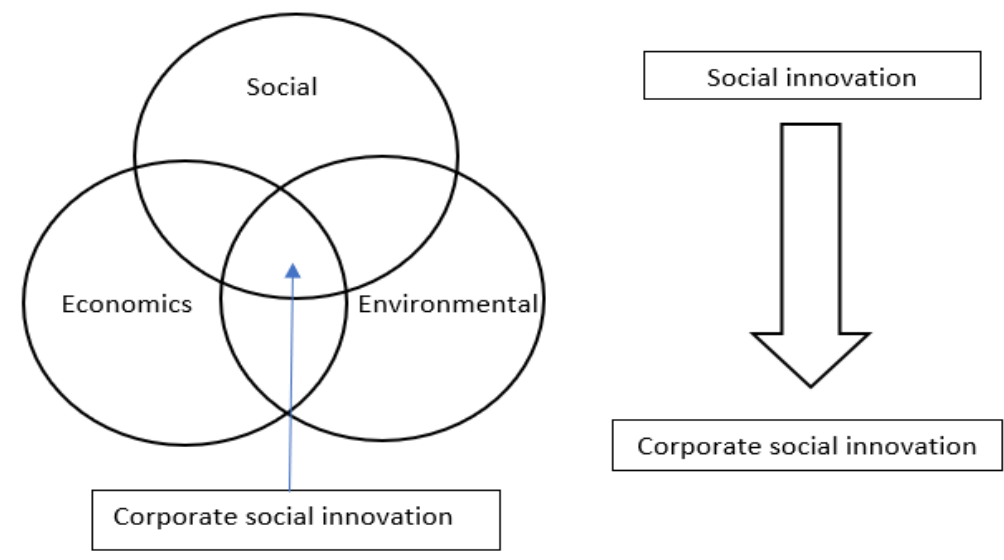

Figure 2: A framework of corporate social innovation

\section{Conclusion}

Accordingly, corporate social innovation is a partnership between public interest and organization interest, and it is reasonable to be the corporate culture in the organizations. The robust transformation of social innovation to corporate social innovation in recent years casts in response to an acceleration of global crises. Therefore, corporate social innovation is relevance to become as a vital business strategy in aligning economic, social, and environmental challenges which could be better relationship between businesses, stakeholders, society, and communities in mitigating the creation of shared value. Therefore, corporate social innovation viewed as the answer to business model in enhancing community well-being tie up to the social worth, create the economic advantages and benefitting environment angle (Kocziszky et al., 2017; Mariann \& Krisztina, 2018).

\section{Acknowledgement}

The author would like to give special thanks to the supervisor and co-supervisor at Kolej Universiti Polytech Mara. 


\section{Reference}

Altuna, N., Maria, A., Claudio, C., Era, D., Frattini, F., \& Maccarrone, P. (2015). Managing social innovation in for-profit organizations: the case of Intesa Sanpaolo.

Cajaiba-santana, G. (2014). Technological Forecasting \& Social Change Social innovation : Moving the fi eld forward . A conceptual framework. Technological Forecasting \& Social Change, 82, 42-51. https://doi.org/10.1016/j.techfore.2013.05.008.

CRISES. (2014). Centre de recherche sur les innovations sociales. Available at $<$ http://www.crises.uqam.ca/>.

Dionisio, M., \& de Vargas, E. R. (2020). Corporate social innovation: A systematic literature review. International Business Review, 29(2), 101641. https://doi.org/10.1016/j.ibusrev.2019.101641.

Drucker, P. F. (1985) Innovation and Entrepreneurship, Harper \& Row Publishers, Inc., New York

Esen, A., \& Maden-Eyiusta, C. (2019). Delineating the concept of corporate social innovation: Toward a multidimensional model. International Journal of Entrepreneurship and Innovation Management, 23(1), 23-45. https://doi.org/10.1504/IJEIM.2019.096497.

Hilb, M. (2005) Corporate Social Impact Innovation - An Empirical Study of Corporate Citizenship Initiatives in Swiss-Based Multinational Firms, University of St. Gallen.

Howaldt, J., Schröder, A., Kaletka, C., Rehfeld, D., \& Terstriep, J. (2016). Comparative analysis (Mapping 1). Mapping the world of social innovation: A global comparative analysis across sectors and world regions. SI-DRIVE Report D1.4. Dortmund: TU Dortmund.

Jali, M. N., Abas, Z., \& Ariffin, A. S. (2017). Social innovation in the context of strategic knowledge management processes for supply chain performance enhancement. International Journal of Supply Chain Management, 6(2), 209-214.

Kanter, R. M. (1999). From spare change to real change: the social sector as a beta site for business innovation, Harvard Business Review, 77(3), 123-132.

KPMG. (2014) 'Breaking through: how corporate social innovation creates business opportunity' [online] http://www.kpmg.com/Ca/en/IssuesAndInsights/ArticlesPublications/Documents/ 5441-KPMG-Social-Innovation-Report-FY14-web-Final.pdf (accessed 15 May 2015).

Mirvis, P., Herrera, M. E. B., Googins, B., \& Albareda, L. (2016). Corporate social innovation: How firms learn to innovate for the greater good. Journal of Business Research, 69(11), 5014-5021. https://doi.org/10.1016/j.jbusres.2016.04.073.

Mulgan, G., Tucker, S., Ali, R., and Sanders, B. (2007) Social Innovation: What it is, why it matters and how it can be accelerated. Oxford: Skoll Centre for Social Entrepreneurship.

Nicholls, A., Simon, J., \& Gabriel, M. (2015). Dimensions of Social Innovation. New Frontiers in Social Innovation Research, 1-26.

https://scholar.google.nl/scholar?cluster=11413936125424182930\&hl=en\&oi=scholara Irt\#0

Odunlade, O. (2017). Beyond CSR : Evaluation of the concept of Corporate Social Innovation as an alternative to CSR. Beyond CSR: Evaluation of the Concept of Corporate Social Innovation as an Alternative to CSR.

OECD. (2005), Guidelines for collecting and interpret- ing innovation data, oslo Manual, 3rd edition, Paris and brussels: oecd and The european commission.

Osburg, T. (2013) 'Social innovation to drive corporate sustainability', in Osburg T. and Schmidpeter, R. (Eds.): Social Innovation: Solutions for a Sustainable Future, pp.13-22, Springer-Verlag, Berlin.Phills, J., Deiglmeier, K. and Miller, D. (2008) 'Rediscovering Social 
Innovation', Stanford Social Innovation Review, Fall: 34-43.

Phillips, W., Lee, H., Ghobadian, A., O'Regan, N., \& James, P. (2015). Social Innovation and Social Entrepreneurship: A Systematic Review. Group and Organization Management, 40(3), 428-461. https://doi.org/10.1177/1059601114560063.

Schumpeter, J. A. (1939) Business Cycles (New York: McGraw-Hill).

Schwab, K. (2018). the Fourth Industrial Revolution (Industry 4.0) a Social Innovation Perspective. Tạp Chí Nghiên Cứu Dân Tộc, 7(23), 12-21. https://doi.org/10.25073/0866$773 x / 97$.

Tabares, S. (2020). Insights from corporate social innovation: a research agenda. https://doi.org/10.1108/SEJ-08-2019-0057.

Taylor, J. B. (1970). Introducing social innovation. J. Appl. Behav. Sci. 6, 69-77.

The Young Foundation. (2012). Social innovation overview-Part I: Defining social innovation. A deliverable to the project "The theoretical, empirical and policy foundations for building social innovation in Europe." Brussels, Belgium: DG Research.

Van der Have, R., and Rubalcaba, L. (2016). Social innovation research: An emerging area of innovation studies? Research Policy 45 (9): 1923-35. 